\title{
Analysis of the Factors Affecting the Choice of Whether to Internalize or Outsource the Task of Greenhouse Gas Inventory Calculations: The Cases of Indonesia, Vietnam, and Thailand
}

\author{
Masato Kawanishi $^{1 *}$, Makoto Kato ${ }^{2}$, Ryo Fujikura ${ }^{3}$ \\ ${ }^{1}$ Japan International Cooperation Agency (JICA), 5-25, Niban-cho, Chiyoda-ku, Tokyo 102-8012, Japan \\ ${ }^{2}$ Overseas Environmental Cooperation Center, Japan (OECC), 4-19-9, Taito, Taito-ku, Tokyo 110-0016, Japan \\ ${ }^{3}$ Faculty of Sustainability Studies, Hosei University, 2-17-1, Fujimi, Chiyoda-ku, Tokyo 102-8160, Japan
}

Corresponding Author Email: Kawanishi.Masato@jica.go.jp

https://doi.org/10.18280/ijsdp.160115

Received: 5 November 2020

Accepted: 17 January 2021

\section{Keywords:}

capacity development, national greenhouse gas inventory, transparency framework, Paris agreement

\begin{abstract}
Developing countries need to build long-term institutional capabilities for a national greenhouse gas (GHG) inventory under the transparency framework of the Paris Agreement. By selecting three Southeast Asian countries as the cases, Indonesia, Vietnam, and Thailand, the present study comparatively examined their institutional designs for producing the GHG inventories. They are common in terms that their national focal points make the overall coordination and other relevant line ministries provide activity data. A major difference exists regarding who is tasked to perform calculations of GHG inventories. By using the framework of Hood concerning the choice of whether to work through specific performance contracts or through direct employment, this study discussed that the variations between the countries may be associated with their differences in the following two factors: One is the number of potential service providers, as expressed by the number of GHG inventory experts as registered in the roster of the United Nations, and the other is the level of uncertainty about how the task is to be done, as measured by a share of the agriculture, forestry and other land use sector in the national GHG inventory. The development of the endogenous research base can contribute to the long-term improvement in GHG inventories. The finding has implications for assistance in building the transparency-related capacity. Development cooperation with developing countries may extend to identifying the categories that are crucial for their current GHG inventories and collaborating relevant research activities with national experts, including young researchers.
\end{abstract}

\section{INTRODUCTION}

The Paris Agreement [1] enhanced transparency framework (Article 13.1) in order to track respective parties' "nationally determined contributions" (NDCs), which manifest their steps undertaken to mitigate greenhouse gas (GHG) emissions and adapt to the impacts of climate change. The national GHG inventory, disclosed by each of the parties, is an indispensable piece of information (Article 13.7) - it isolates and calculates a country's human-caused GHGs, thus creating a means through which progress towards each country's target for climate change mitigation can be both recorded and monitored. The guidelines of the Inter-governmental Panel on Climate Change (IPCC) [2], state that the principal method for creating a GHG inventory is to take information regarding the degree of human activity, which is referred to as activity data (AD), and combine it with coefficients that quantify the emissions or removals per unit of activity, referred to as emission factor (EF), where emissions $=A D * E F$. Properly collecting and maintaining activity data, however, are tasks that developing countries tend to struggle with. Additionally, rather than measuring country-specific emission factors, "default values", which the IPCC sets, are often used by developing countries. These, however, might not be accurate reflections of the current circumstances of each country.

Interest regarding national GHG inventories is on the rise among policy and research groups. There are three general subdivisions that recent related research can be grouped into. Studies that address the methodological aspects of GHG inventories are one of these subdivisions. These studies are done to estimate GHG inventories more accurately through the development of country-specific emission factors and/or estimation methods. Agriculture, forestry, and other land use (AFOLU) sectors are often the primary focus. For example, manure from American dairy farms [3], forest degradation in developing countries [4], broiler husbandry in Portugal [5], coastal wetlands in the United States [6], Canadian managed forest [7], harvested wood products in several countries [8], and drained organic soils in Germany [9] have been recently studied. Analysis in this first subdivision often focuses on developed countries. The fact that developed countries tend to have more readily available data may be a contributing factor in this.

The second subdivision of studies includes ones that evaluate and review GHG inventories that have been reported. Pulles [10] analyzed the changes in reported GHG emissions that were made as a result of the review comments under the United Nations Framework Convention on Climate Change (UNFCCC or the Convention), thereby evaluating the relevance of the international review process. Jarnicka and Żebrowski [11] discussed trends in the quality of GHG 
inventories in the EU and its member countries by analyzing the changes in their reported uncertainties over time.

The third subdivision includes studies that are focused on assessing the capacity to which a country can prepare a national GHG inventory. There is a high volume of study that has centered around the difficulties that developing countries encounter in regard to building the capacity necessary to facilitate reporting at a higher frequency. Bustamante et al. [12] described Brazil's approach to involving the country's researchers for preparing GHG inventories in the forestry sector. Kawanishi and his colleagues carried out cross-country [13] as well as time-series [14] analyses to evaluate the institutional capacities for GHG inventory preparation in developing countries. Kawanishi and Fujikura [15] also examined the determinative factors in regard to the effectiveness of GHG inventory preparation in Japan, and assessed the applicability in developing countries. Umemiya et al. [16] applied a matrix of capacity indicators to analyze the present condition and any shifts in the capacity of developing Asian countries. Umemiya et al. [17] also utilized case studies in Vietnam and Cambodia to assess past trends in capacity development assistance.

However, to our knowledge, no study has addressed a choice of whether to internalize or outsource the task of GHG inventory calculations, even though this is one of the key dimensions for countries' institutional arrangements. Internalization is defined in this paper as calculating national GHG inventories through direct employment, while outsourcing means performing this task through specific service contracts. This study attempts to isolate potential factors that differentiate this choice by using the framework of Hood [18]. To accomplish this, we will compare the institutional designs for producing the GHG inventories in three countries in Southeast Asia: Indonesia, Vietnam, and Thailand, with a particular attention to the roles of experts in each country.

This paper will first outline the transparency framework that has been applied to developing countries by the UNFCCC and then enhanced with the Paris Agreement. After describing the analytical framework and the method applied in this study, we present the institutional design of the national GHG inventory in each country. This paper will then examine potential factors that differentiate the institutional arrangements between the three countries as well as discuss the implications for capacity development assistance for GHG inventories in developing countries.

\section{TRANSPARENCY FRAMEWORK}

The importance of transparency to the successful implementation of international agreements has long been recognized. Transparency is defined as "the generation and dissemination of information about the requirements of the regime and the parties' performance under it" [19]. With increases to transparency, the visibility of behaviors and violations to others is raised. It is because of this that verification may have an impact on member parties' behavior and ultimately play a part in the effectiveness of agreements. [20]. In instances of noncompliance with international environmental agreements, there is rarely a penalty leveraged, but rather peer or public pressure resulting from data put forth by the parties themselves regarding the implementation serves as the principal enforcement mechanism [21].
The transparency framework under the Paris Agreement has created a sizeable amount of recent research interest. Obergassel et al. [22] determined that the Paris Agreement is reliant upon a mechanism of "naming and shaming" to guarantee compliance with obligatory transparency and review provisions, placing substantial demands for information on all parties as well as subjecting information to analysis. Falkner [23] also specified that the Paris Agreement's establishment of a system of mandatory national reporting designates transparency as a crucial means of regulation. He argued that the review mechanism will likely serve to leverage peer pressure on states. It will regularly generate opportunities for "naming and shaming" to be utilized against countries which fail to meet the expectations of the international community. Mitigation pledges are set forth by each individual member country itself and thus enforcement via the regime's compliance mechanism is not possible; leaving international review and peer pressure as the primary multilateral device for parties to increase the believability of their pledges. Bodansky [24] came to a similar conclusion, asserting that "states will have an incentive to carry out their NDCs because, if they don't, everyone will know, subjecting them to peer and public pressure". There is no obligation for countries to actualize their submitted NDC targets, thus the transparency framework is "the main mechanism to hold states accountable for doing what they say".

The enhanced transparency framework under the Paris Agreement, being applicable to each party, improves upon and ultimately surpasses the conventional transparency arrangements under the UNFCCC, which are described as "a bifurcated system that placed differing transparency requirements on developed and developing countries" [25]. The agreements regarding non-Annex I countries (developing countries) have been constituted of national communications (NCs) and biennial update reports (BURs), through which information regarding national GHG inventory is provided [26, 27]. It is stated in the Cancun Agreements, as adopted in 2010 in Mexico, that non-Annex I countries should present their NCs every four years [27] (Decision 1/CP.16, paragraph 60(b)). It was agreed in 2011 in Durban, South Africa that nonAnnex I countries should submit their initial BUR by the end of 2014 (Decision 2/CP.17, paragraph 41(a)) and shall submit BURs every two years thereafter [28] (Decision 2/CP.17, paragraph 41(f)). Submitted BURs are subjected to consultation and analysis (ICA) with the "aim to increase the transparency" via scrutiny by global technical experts and a facilitative sharing of views [29].

The effective implementation of the transparency framework depends to a large extent on capacities of developing countries to establish sustainable institutional arrangements for regularly updating GHG inventories. One of the key dimensions of their institutional designs is a choice of whether to internalize or outsource the task of GHG inventory calculations, which is the focus of this paper.

\section{METHOD}

\subsection{Analytical framework and its application to this study}

Hood [18] elaborated on the choice of "whether to work through specific performance contracts or through direct employment" as one of the key dimensions for organizing public service. By citing Williamson [30], Hood identifies two 
factors that are likely to lead to the use of direct employment rather than performance contracts: "Uncertainty" about how to proceed with a task and "small numbers of parties to a transaction".

First, "the more uncertain ... a task is, the harder it becomes to draw up contracts to cover all the contingencies which may conceivably arise". Hood describes that an employee can be directed to deal with problems as they happen, but an enforceable contract must take care of all the contingencies in advance. In case there is less uncertainty about how the job is to be done, it is easier to specify quality of performance, which may be why such services are very often not provided by direct public service employees. The task uncertainty should not be mistaken for uncertainty of a GHG inventory itself, which is specified as a "lack of knowledge of the true value" [2].

Hood also identifies numbers of potential service providers as the second factor that affects a choice of whether to internalize or outsource the task. He states that "the fewer the buyers and/or sellers involved, the less is likely to be the advantage of using performance contracts rather than employment". Where there are many sellers and buyers, the process of completing transactions will tend to be simplified and standardized. In the extreme case where a single seller confronts a single buyer, it is likely to be very difficult to agree to a deal. An employment contract, once agreed to, may reduce such difficulty.

The budget availability may also potentially affect the choice of either direct employment or service contract. However, for compiling and reporting GHG inventories under the UNFCCC, developing countries can access to the funding support of the Global Environment Facility (GEF). Therefore, the government budget was not included among significant factors that determine the above-mentioned choice under this study.

The availability of inhouse staff with technical expertise may be a potential factor as well. However, this is considered as a dependent rather than independent variable. As will be discussed later, the case of Indonesia indicates that the capacity building efforts for internal staff have been strengthened under the influence of the factors as identified by Hood.

In applying the analytical framework of Hood to this study, we established indicators and data for measurement for each of the above-mentioned two factors, as summarized in Table 1. As for the task uncertainty, we sought an expert opinion from the Mitigation, Data and Analysis (MDA) of the UNFCCC, one of the programmes at the secretariat, which oversees matters related to the transparency framework under the Paris Agreement. Although the latest IPCC guidelines [2] provide a certain level of clarity as to how to proceed with the task of producing a GHG inventory, our interview with GHG inventory experts at the UNFCCC/MDA programme indicates that a share of the AFOLU sector in the national GHG inventory may differentiate the task uncertainty across countries; the higher the share, the more uncertain the task of national GHG inventory preparation. In fact, the IPCC states that "the AFOLU sector has some unique characteristics with respect to developing inventory methods. There are many processes leading to emissions and removals of greenhouse gases, which can be widely dispersed in space and highly variable in time" [2]. It also states that "estimating changes in carbon pools and fluxes depends on data and model availability, as well as resources and capacity to collect and analyze additional information" [2]. Due to such complexity, it is not easy to identify all the contingencies that may arise in advance.

Under the latest IPCC guidelines [2], the AFOLU sector has integrated two sectors: (1) agriculture and (2) land use, landuse change and forestry (LULUCF), which had been separately guided under the previous version of the IPCC guidelines [31]. We thus calculated the shares of the AFOLU sector, or the sum of the agriculture and LULUCF sectors where applicable, in the national GHG inventories in Indonesia, Vietnam, and Thailand. These calculations were made in reference to the key category analyses in the national GHG inventories as reported in their submissions to the UNFCCC. A key category is defined as "one that is prioritized within the national inventory system because its estimate has a significant influence on a country's total inventory of greenhouse gases in terms of the absolute level, the trend, or the uncertainty in emissions and removals" [2]. The three countries have identified their key categories as "those that, when summed together in descending order of magnitude, add up to 95 percent of the total level" [2]. In the present study, we extracted all the key categories in the AFOLU sector (or the agriculture and LULUCF sectors where applicable) and summed their percentage contributions to the respective countries' GHG inventories

We also established two indicators that may indirectly measure numbers of potential service providers. One is the number of experts on GHG inventory, as registered at the UNFCCC roster as of November 2020 [32]. The other is the statistics of the World Bank regarding numbers of researchers engaged in research and development activities [33].

Table 1. Indicators and data for measurement for the analysis of direct employment versus service contracts

\begin{tabular}{|c|c|c|}
\hline Factors & Indicators & $\begin{array}{c}\text { Data for } \\
\text { Measurement }\end{array}$ \\
\hline $\begin{array}{c}\text { Task } \\
\text { uncertainty }\end{array}$ & $\begin{array}{l}\text { Shares of the } \\
\text { agriculture, forestry } \\
\text { and other land use } \\
\text { (AFOLU) sector in } \\
\text { the national } \\
\text { greenhouse gas } \\
\text { (GHG) inventory }\end{array}$ & $\begin{array}{l}\text { Extracted all the key } \\
\text { categories in the } \\
\text { AFOLU sector and } \\
\text { summed their } \\
\text { percentage } \\
\text { contributions to the } \\
\text { national GHG } \\
\text { inventories }\end{array}$ \\
\hline \multirow{2}{*}{$\begin{array}{l}\text { Number of } \\
\text { potential } \\
\text { service } \\
\text { providers }\end{array}$} & $\begin{array}{l}\text { Numbers of experts } \\
\text { on GHG inventory }\end{array}$ & $\begin{array}{l}\text { International expert } \\
\text { roster under the United } \\
\text { Nations Framework } \\
\text { Convention on Climate } \\
\text { Change }\end{array}$ \\
\hline & $\begin{array}{l}\text { Numbers of } \\
\text { researchers engaged } \\
\text { in research and } \\
\text { development } \\
\text { activities }\end{array}$ & World Bank statistics \\
\hline
\end{tabular}

\subsection{Data collection and coding for case description}

The present study compared institutional designs for producing the national GHG inventories between three countries in Southeast Asia: Indonesia, Vietnam, and Thailand. These countries were chosen as they are similar in terms of frequency and timing of submissions of their NCs and BURs. As shown in Table 2, they have reported three NCs and two BURs as of November 2020, respectively. The present study examined whether, despite this similarity, differences may exist in their institutional arrangements for producing the 
GHG inventories. Particular attention was paid to the roles of experts, as well as the overall lead agency and sectoral coordinating agencies [34]. In this study, we define "experts" as national experts working outside these agencies, unless otherwise stated. For the attempt to identify a potential factor for the difference, a choice of whether to internalize or outsource the task of GHG inventory calculations was examined by using the framework of Hood [18].

Table 2. Years of submission of national communications (NCs) and biennial update reports (BURs)

\begin{tabular}{lcccrr}
\hline & NC1 & NC2 & NC3 & BUR1 & BUR2 \\
\hline Indonesia & 1999 & 2011 & 2018 & 2016 & 2018 \\
Vietnam & 2003 & 2010 & 2019 & 2014 & 2017 \\
Thailand & 2000 & 2011 & 2018 & 2015 & 2017 \\
\hline \multicolumn{2}{l}{ Note: Status of submission as of November $2020[35,36]}$.
\end{tabular}

Interviews with Indonesia's Ministry of Environment and Forestry (KLHK), Vietnam's Ministry of Natural Resources and Environment (MONRE), and Thailand's Office of Natural Resources and Environment Policy and Planning (ONEP), which each serve as their respective country's focal points on climate change, were the source of information and data regarding institutional designs for the national GHG inventories for use in this study. Interviewees also included individuals familiar with these countries' national reporting, such as experts from universities and research institutes, as well as relevant donor agencies. The interviews took place in Hanoi in October 2018, Jakarta in June 2019, and Bangkok in August 2019. The following questions were sent to the interviewees beforehand to provide them with ample time to remember pertinent past events: (1) How is the national GHG inventory currently produced? Who is involved? What are their respective roles? How are their roles related to each other? (2) What was in place before the present situation? Why has the institutional arrangement changed over time? (3) How has the capacity for a national GHG inventory been developed? What are the key factors for the capacity development?

One author facilitated semi-structured interviews based on the above questions, and the other authors raised additional questions where necessary for making sure to identify the relevant actors and understand their respective roles and interactions. We recorded the interviews by note-taking and converted the notes into a typed format soon after each interview took place. Interview data were then categorized into the roles of the overall lead agency, sectoral coordinating agencies, and experts. We conducted the above categorization of the interview data manually. We placed handwritten annotations on the transcripts.

In addition, the countries' submitted NCs and BURs were carefully reviewed. Their national policy and regulatory documents, as well as relevant agreements and decisions under the UNFCCC, were also closely examined. These document reviews were conducted and described by one author, which were then confirmed by the other authors.

\section{RESULT}

\subsection{Institutional designs for national GHG inventories in three countries in Southeast Asia}

\subsubsection{Indonesia}

Shortly after taking office in October 2014, President Joko
Widodo issued the Presidential Regulation No. 165/2014, in which he declared that the Ministry of Environment (KLH) and the Ministry of Forestry would be merged, thereby forming KLHK [37]. In January 2015, he also issued the Presidential Regulation No. 16/2015 to establish the Directorate General of Climate Change at KLHK [38]. This Regulation dissolved the National Council on Climate Change (DNPI), which had been appointed as the country's national focal point for the UNFCCC since 2008, as well as the REDD+ Agency, which had been established since 2013 with an order for overall coordination for the activities to decrease GHG emissions caused by deforestation and forest degradation in Indonesia. The President transferred the functions of these two agencies to KLHK and gave authority over them to the abovementioned Directorate General. This delegation was carried out in an effort to do away with concurrent jurisdiction and consolidating authority relating to climate change.

With its status as the national focal point for the UNFCCC, KLHK's responsibilities now include both the submission of the national GHG inventories and biennially updating them. From the interviews, we have come to understand that decision-makers at KLHK feel that continuing to depend on the few experts they had, which there were only four core experts, is unsustainable. Rather, there is a definite interest in developing an internal capacity for updating GHG inventories on a regular basis.

In April 2015, the Ministerial Regulation No. P.18/MENLHK-II/2015 on the organization and functions of KLHK was issued [39]. Along with four other directorates, the Directorate of GHG inventory and Measurement, Reporting, and Verification (MRV) was newly formed under the Directorate General of Climate Change. KLH used to have a unit in charge of national GHG inventories, which, however, was only a part of the Directorate of Mitigation. KLHK has thus scaled up the national GHG inventory issue on the administrative scale, creating greater visibility of the issue [40, 41]. Twelve technical staff are at this directorate on a regular basis, as opposed to the six staff in charge at the time of KLH.

In addition, steps like training the staff, and creating an online data system that KLH took beforehand with aid from donors have created positive impacts [42, 43]. KLHK has finished developing the so-called SIGN-SMART system for enabling pertinent line ministries and local governments to provide activity data without difficulty. This Web-based instrument went online by 2015 . KLHK is continuously working to expand the capabilities of internal staff by facilitating transfers of knowledge and skills from experts and donor-funded staff. Moreover, it has developed key performance indicators for staff appraisals. Frequent updates of GHG inventories are among those indicators as applied to the staff in charge.

In December 2017, the Ministerial Regulation No. P.73/MENLHK/SETJEN/KUM.1/12/2017 on national GHG inventory implementation and reporting guidelines was issued [44]. While as of now KLHK produces the GHG inventory using activity data provided by other relevant ministries, the above-mentioned Ministerial Regulation envisions that the relevant ministries would produce their respective sector inventories themselves, after which KLHK would validate then compile them. [45, 46].

The country's first BUR [47] was submitted in 2016. KLHK was able to create the national GHG due to a sizeable amount of assistance from experts and donor-funded staff. The second BUR [46] was submitted by the end of 2018, for which internal 
staff of KLHK produced the GHG inventory on their own for the first time. Experts only stepped in to give technical advice when necessary. Thus, the task of producing the GHG inventory, which used to be completed by external experts, has become an inhouse task completed within KLHK. The technical analysis of the ICA for the second BUR has praised Indonesia for using the 2006 IPCC guidelines and for advancing to a higher tier (i.e., level of methodological complexity) for estimating some parts of the inventory's GHG emissions and removals [48].

\subsubsection{Vietnam}

MONRE is the permanent acting agency of the National Committee on Climate Change as well as the national focal point for the UNFCCC in Vietnam. This Committee, which was formed under the Prime Minister's Decision No. 43/QDTTg in 2012, is chaired by the Prime Minister and composed of representatives of relevant ministries [49].

It was through the Prime Minister's Decision No. 2359/QDTTg that the national system for GHG inventory was established [50]. Vietnam has made clear their commitment to meeting their reporting objectives under the Convention by declaring "biennially" updating and "ensuring the accountability as the party to the UNFCCC". This Decision has designated the MONRE as the overall lead agency for putting together the GHG inventory. Furthermore, it designated four additional ministries-Ministries of Industry and Trade; Transportation; Agriculture and Rural Development; and Construction - as sectoral coordinating agencies to put forth activity data and other pertinent information within their respective jurisdictions.

The interviews conducted for this study also revealed that Vietnam has formed a team of experts tasked with GHG inventory. This team is comprised of ten experts dispatched from institutes and agencies with affiliations with the MONRE, such as the Vietnam Institute of Meteorology, Hydrology, and Climate Change (IMHEN), the Institute of Strategy and Policy on Natural Resources and Environment (ISPONRE), Vietnam Environment Administration (VEA), and the Centre of Technology Responding to Climate Change (CliTech). Terms of reference for each expert are detailed by the MONRE. The team is comprised of sector experts that work intimately with their respective ministries in order to acquire activity data in the case that the information is not easily accessible in the General Statistical Office of Vietnam. Quantifying sectoral GHG inventories following the collection of activity data is the responsibility of sector experts. As such, the provision of activity data and other information as requested are the only responsibilities of the respective line ministries, and they are not required to quantify their sectoral GHG inventories. There is extraordinarily little change in regard to the members of each team over time, meaning they can work to archive as well as maintain the database, manuals, and other resources used in the preceding cycles of GHG inventory compilation.

The interviewees indicated that their capacities were developed significantly with donor supports [51]. This is demonstrated by the fact that among them there are some who have been added onto the roster of international experts after passing the examination for review experts. Upon a member's resignation from the team, the MONRE guarantees that their technical expertise is passed down to newly-retained experts Through interviews for this study, we learned that the expert team is capable of coordinating amongst themselves efficiently, devoid of any major friction. Care is taken under the MONRE's supervision that team members take the consistent methodological approach across the various categories. Additionally, they confirm with each other as a measure to prevent any double-counting of GHG emissions and/or absorptions.

The national GHG inventory reported in the first BUR was produced with considerable donor assistance [52]. The technical analysis as part of an ICA, which took place in 2015 on the initial BUR, commended "the considerable progress made in improving the process for national GHG inventory preparation and the updating of the methodology used in the estimation" [53]. For the country's second BUR, the GHG inventory was produced in a much more self-reliant manner [54]. The country was praised for "enhancing the transparency of the information reported" [55] in the technical analysis on the second BUR, which was conducted in March 2018.

\subsubsection{Thailand}

The National Committee on Climate Change Policy (NCCC), established in 2007, is chaired by the prime minister with the ONEP serving as a secretariat [56]. Attendees include the relevant ministries and agencies' representatives. The NCCC is responsible for (1) formulation of national climate change policies and strategies; and (2) monitoring and evaluating their implementation. There are four subcommittees under the NCCC, one of which is the SubCommittee on Climate Change Knowledge and Database. Under this Sub-Committee, five sectoral working groups have been established to review the GHG inventories.

With the decision by the NCCC, the process for producing national GHG inventories has been formalized since 2015, consisting of the following steps $[56,57]$ : The relevant line ministries collect and provide activity data to the ONEP. Using these activity data, experts, who are contracted by the ONEP, perform GHG inventory calculations. The results are reviewed by the above-mentioned five working groups to ensure that the methodologies to estimate GHG emissions and/or absorptions are valid for their respective sectors. Upon approval by the working groups, the GHG inventory is sent to the SubCommittee on Climate Change Knowledge and Database for verification, after which it is submitted to the NCCC for authorization.

Throughout the above process, the ONEP provides overall coordination. At the time of the interview, the number of staff regularly assigned to the ONEP for the GHG inventory is six. One of them is responsible for overall management and the other members oversee their respective sectoral GHG inventories. Their tasks are also supported by one or two contract-based staff.

The ONEP provides other relevant line ministries with methodological guidance concerning collection of activity data. Training is also provided to responsible staff at these ministries through the Climate Change International Technical and Training Centre (CITC), which has been formed and operating under the Thailand Greenhouse Gas Management Organization (TGO) [58]. While funding aid by the GEF covers the cost of producing the GHG inventories, including the cost of contracting experts, a government budget is allocated to the relevant line ministries for collecting activity data. The associated performance indicators are also assigned to these ministries.

Experts belong to the country's academic institutions, such as Thammasat University, Kasetsart University, and King Mongkut's University of Technology North Bangkok and 
Thonburi. The ONEP contracts with these universities to mobilize around 20 experts in total. Among these experts, some have managed to pass the UNFCCC's examination for review experts. In June 2016, the ONEP and the Australian Department of the Environment and Energy signed the minutes of understanding for cooperation to establish Thailand's GHG Emissions Inventory System (TGEIS). This system would enable automatic quantification of GHG inventories. The interviews in this study have indicated that, with the establishment of this system, the role of experts would be changed from GHG inventory calculations to quality assurance.

Thailand submitted its initial and second BURs in 2015 and 2017 , respectively $[56,59]$. The technical analysis as part of an ICA, which took place in March 2018 on the submitted second BUR, commends the country for "enhancing the transparency of the information reported" [60]. Thailand's compliance with IPCC guidelines and the UNFCCC reporting guidelines was also reported.

\subsection{Analysis of direct employment versus performance contracts}

Table 3 summarizes the roles of the overall lead agency, sectoral coordinating agencies, and experts outside these agencies in Indonesia, Vietnam, and Thailand.

Table 3. Roles of the overall lead agency, sectoral coordinating agencies, and experts for the national greenhouse gas (GHG) inventory

\begin{tabular}{|c|c|c|c|}
\hline & Indonesia & Vietnam & Thailand \\
\hline $\begin{array}{c}\text { Overall lead } \\
\text { agency }\end{array}$ & $\begin{array}{c}\text { The Ministry } \\
\text { of Forestry } \\
\text { and } \\
\text { Environment } \\
\text { (KLHK) } \\
\text { performs } \\
\text { calculations of } \\
\text { the national } \\
\text { GHG } \\
\text { inventory as } \\
\text { well as } \\
\text { provides } \\
\text { overall } \\
\text { coordination. }\end{array}$ & $\begin{array}{c}\text { The Ministry } \\
\text { of Natural } \\
\text { Resources } \\
\text { and } \\
\text { Environment } \\
\text { (MONRE) } \\
\text { provides } \\
\text { overall } \\
\text { coordination. }\end{array}$ & $\begin{array}{c}\text { The Office of } \\
\text { Natural } \\
\text { Resources } \\
\text { and } \\
\text { Environment } \\
\text { Policy and } \\
\text { Planning } \\
\text { (ONEP) } \\
\text { provides } \\
\text { overall } \\
\text { coordination. }\end{array}$ \\
\hline $\begin{array}{c}\text { Sectoral } \\
\text { coordinating } \\
\text { agencies }\end{array}$ & $\begin{array}{l}\text { Collect } \\
\text { activity data } \\
\text { and provide it } \\
\text { to KLHK. }\end{array}$ & $\begin{array}{l}\text { Collect } \\
\text { activity data } \\
\text { and provide it } \\
\text { to the experts } \\
\text { contracted by } \\
\text { the MONRE. }\end{array}$ & $\begin{array}{l}\text { Collect } \\
\text { activity data } \\
\text { and provide it } \\
\text { to the ONEP. }\end{array}$ \\
\hline $\begin{array}{l}\text { National } \\
\text { experts } \\
\text { outside the } \\
\text { above } \\
\text { agencies }\end{array}$ & $\begin{array}{l}\text { Provide } \\
\text { technical } \\
\text { advice. }\end{array}$ & $\begin{array}{l}\text { Contracted by } \\
\text { the MONRE } \\
\text { to perform } \\
\text { calculations } \\
\text { of the GHG } \\
\text { inventory. }\end{array}$ & $\begin{array}{c}\text { Contracted by } \\
\text { the ONEP to } \\
\text { perform } \\
\text { calculations } \\
\text { of the GHG } \\
\text { inventory. }\end{array}$ \\
\hline
\end{tabular}

They are common in terms that their national focal points make the overall coordination and other relevant line ministries provide activity data. A major difference exists regarding who is tasked to perform calculations of national GHG inventories, as summarized in Table 4. In Indonesia, although this task used to be provided by external experts, it is now completed inhouse within KLHK. In Thailand, this task is outsourced to experts at universities. In the case of Vietnam, the MONRE contracts with experts, all of whom belong to its affiliated research institutes.

Table 4. Similarity and difference in national greenhouse gas (GHG) inventory preparation between three Southeast Asian countries

\begin{tabular}{|c|c|c|c|}
\hline & Indonesia & Vietnam & Thailand \\
\hline Similarity & \multicolumn{3}{|c|}{$\begin{array}{l}\text { National focal points make the overall } \\
\text { coordination and other relevant line ministries } \\
\text { provide activity data. }\end{array}$} \\
\hline $\begin{array}{c}\text { Difference } \\
\text { regarding } \\
\text { who is tasked } \\
\text { with GHG } \\
\text { inventory } \\
\text { calculations }\end{array}$ & $\begin{array}{l}\text { The Ministry } \\
\text { of Forestry } \\
\text { and } \\
\text { Environment } \\
\text { (KLHK) itself }\end{array}$ & $\begin{array}{c}\text { Experts at } \\
\text { research } \\
\text { institutes } \\
\text { affiliated with } \\
\text { the Ministry of } \\
\text { Natural } \\
\text { Resources and } \\
\text { Environment } \\
\text { (MONRE) }\end{array}$ & $\begin{array}{l}\text { Experts at } \\
\text { universities }\end{array}$ \\
\hline
\end{tabular}

Table 5 presents the shares of the AFOLU sector (or the sum of the agriculture and LULUCF sectors where applicable) in the national GHG inventories in Indonesia, Vietnam, and Thailand. Their percentage contributions were calculated for multiple years, where data was available, in consideration of potential year-to-year variations. Table 5 clearly shows that the AFOLU sector is dominant in Indonesia, accounting for about two thirds of its national GHG inventory. By contrast, the agriculture and LULUCF sectors, in combination, account for just over a third of the respective countries' GHG inventories in Vietnam and Thailand, making much less contributions than in the case of Indonesia. Such a difference suggests that the national GHG inventory preparation may involve more task uncertainty in Indonesia than in the other two countries.

Table 5. Significance of the land-use related sector in the national greenhouse gas ( $\mathrm{GHG}$ ) inventory

\begin{tabular}{|c|c|c|c|}
\hline & Indonesia $^{1}$ & Vietnam $^{2}$ & Thailand $^{3}$ \\
\hline \multirow{2}{*}{$\begin{array}{l}\text { Percentage contributions } \\
\text { of the agriculture, } \\
\text { forestry and other land } \\
\text { use (AFOLU) sector, or } \\
\text { the combined } \\
\text { contributions of the } \\
\text { agriculture and the land } \\
\text { use, land-use change } \\
\text { and forestry (LULUCF) } \\
\text { sectors, to the national } \\
\text { GHG inventories (\%) }\end{array}$} & $\begin{array}{c}65.9 \\
(2014) \\
\end{array}$ & $\begin{array}{c}37.6 \\
(2013) \\
\end{array}$ & $\begin{array}{c}36.7 \\
(2013)\end{array}$ \\
\hline & $\begin{array}{c}63.0 \\
(2016)\end{array}$ & $\begin{array}{c}35.7 \\
(2014)\end{array}$ & - \\
\hline $\begin{array}{l}\text { otes. 1. Key categories in } \\
\text { ventories in the years } 201 \\
\text { spectively. 2. Key categories } \\
\text { tional GHG inventories in th } \\
\text { 9], respectively. 3. Key cate } \\
\text { r the national GHG inventor }\end{array}$ & $\begin{array}{l}\text { AFOLU } \\
\text { and } 2016 \text {, } \\
\text { the agricul } \\
\text { ears } 2013\end{array}$ & $\begin{array}{l}\text { or for } \\
\text { ported } \\
\text { ad LUL } \\
14 \text {, as 1 }\end{array}$ & $\begin{array}{l}\text { tional GHG } \\
\text { 5] and [46], } \\
\text { ectors for the } \\
\text { d in [54] and } \\
\text { UCF sectors } \\
\text { 57]. }\end{array}$ \\
\hline
\end{tabular}

Table 6 presents that the numbers of potential suppliers of the service for producing national GHG inventories vary across the countries. It shows that Thailand has three times larger the number of experts on GHG inventory, as registered at the UNFCCC roster, than Indonesia. It also indicates a significant difference that exists in the research base, as may be expressed by numbers of researchers engaged in research and development activities, between Indonesia and Thailand. Vietnam is positioned between Indonesia and Thailand in 
terms of both above two statistical figures.

Table 6. National scientific and technical capacities

\begin{tabular}{cccc}
\hline & Indonesia & Vietnam & Thailand \\
\hline $\begin{array}{c}\text { Number of experts in GHG } \\
\text { inventory registered in the } \\
\text { roster under the United } \\
\text { Nations Framework }\end{array}$ & & & \\
Convention on Climate & & 13 & 27 \\
$\begin{array}{c}\text { Change, as of November } \\
\text { 2020 [35] }\end{array}$ & & & \\
$\quad \begin{array}{l}\text { Number of researchers } \\
\text { involved in research and } \\
\text { development per million } \\
\text { people (most recent data } \\
\text { and year) [36] }\end{array}$ & 216 & 708 & 1,350 \\
& & & \\
\hline
\end{tabular}

\section{DISCUSSION}

\subsection{Status and prospect of the choice of whether to internalize or outsource GHG inventory calculations}

The matrix of a level of the task uncertainty and the number of potential service providers is graphically displayed in Figure 1. The area marked IV on the graph combines a high uncertainty with a limited number of potential suppliers, representing an unpromising ground for performance contracting. On the other hand, the area marked II indicates a greater certainty as to how the task should be done, combined with the existence of many potential service providers, representing a stronger case for specific performance contracts.

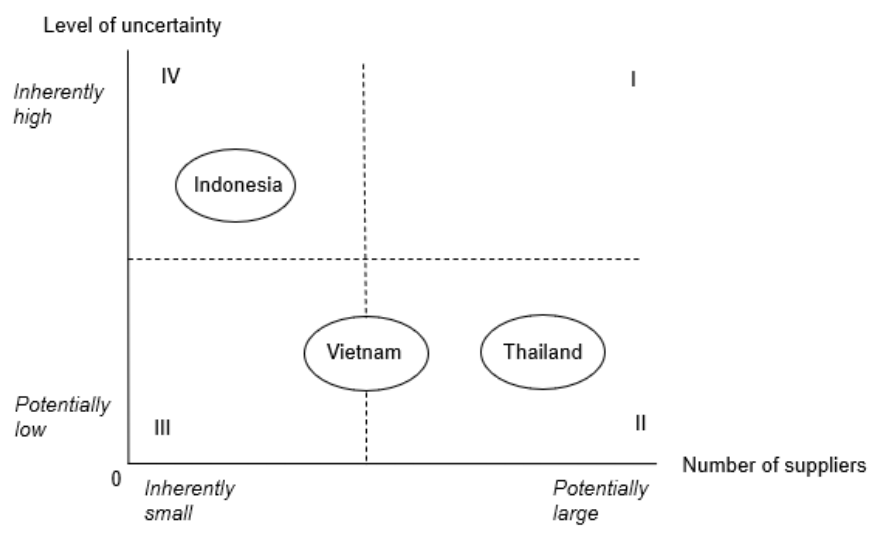

Figure 1. 2x2 matrix based on Hood [18]

Figure 1 also displays the relative positions of the tasks for producing the national GHG inventories in the three countries. The case of Thailand represents a relatively larger number of potential service providers, combined with a relatively lower uncertainty as to how to perform the task. It is, therefore, a stronger case than the two other countries for a specific performance contract. On the other hand, the case of Indonesia is associated with a smaller number of potential service providers, combined with a relatively higher task uncertainty. It, therefore, represents a weaker case for a performance contract. It is worth recalling the interview results in this study, which have made clear that decision-makers at KLHK of Indonesia found continuing to depend on a small group of experts to be untenable and instead had great interest in fostering the Ministry's internal capacity for quantification of the GHG inventory in a sustainable manner. The case of Vietnam is relatively situated between the cases of Indonesia and Thailand. The MONRE of Vietnam contracts with experts for performing calculations of the national GHG inventory. However, all these experts belong to the research institutes affiliated with the MONRE, and, therefore, they may be directed to deal with problems when they happen. Thus, the case of Vietnam may be considered as representing a hybrid form of direct employment and specific performance contracts.

In the choice between internalizing or outsourcing the task of national GHG inventories, there is no objectively right or wrong choice. However, as the process of regularly updating GHG inventories continues under the Paris Agreement, it may be expected that a level of task uncertainty will be lowered, being accompanied with an increase in the number of potential service providers over time in each country. In other words, it is anticipated that many developing countries move diagonally from the area IV toward II in Figure 1, resulting in the increasing number of cases for specific performance contracts with experts for GHG inventory preparation. It may be said that Indonesia, currently located in the area IV, has taken the right choice by internalizing the task for the moment. However, the country would likely move to the area II in the future by outsourcing the task, as is the case of Thailand and Vietnam.

\subsection{Implications for capacity development assistance}

The above observation has implications for capacity development assistance. When support for building the transparency-related capacity is provided to developing countries, the probable shift to the area II should be kept in mind. Developing a network of endogenous researchers would enable the concerned country to move to the right in Figure 1. The advancement of relevant research activities, on the other hand, would contribute to reducing the level of task uncertainty, thereby inducing a downward shift in Figure 1. To this end, development cooperation may involve identifying the categories that are crucial for current GHG inventories and collaborating the relevant research activities with endogenous researchers. Young researchers should also be engaged to ensure knowledge transfer between generations.

The interviews in this study have indicated that the role of experts is important no matter whether they currently perform calculations for a GHG inventory or only provide technical advice. Most importantly, experts retain institutional memory despite periodic changes in government staff in charge. This is exemplified by the case of Vietnam, where the expert team fulfills an archiving role by maintaining items utilized in the past GHG inventory preparation such as database and technical guidance. The cases of Indonesia and Thailand also point to the important role of experts during evolving changes in their national GHG inventory systems. However, none of these countries has yet systematized the incorporation of relevant research findings into their GHG inventories. Such channel would enable endogenous research bases to develop, thereby supporting the improvements in GHG inventories in the long-term.

\section{CONCLUSION}

The primary contribution of this paper lies in its use of the analytical framework of Hood to comparatively investigate the institutional designs for producing the national GHG 
inventories. By selecting three Southeast Asian countriesIndonesia, Vietnam, and Thailand-as the cases, the present study has found that they are different in their choices as to whether to internalize or outsource the task to perform calculations for the GHG inventory. This study discussed that it may be linked to the differences in the numbers of potential service providers between the countries, as well as the level of uncertainty about how the task is to be done.

We recognize the need to further test the validity of the findings. In applying the framework of Hood to this study, we utilized a share of the AFOLU sector in the national GHG inventory as an indicator for the task uncertainty. However, other additional indicators may potentially exist, such as the competence of an overall lead agency, the smoothness of communication among pertinent ministries and agencies, the status of collection and maintenance of national statistical data, and the status of information network systems. Further research is needed to identify a set of data that can measure these potential indicators, thereby comparing the levels of task uncertainty across countries.

Future work may also address the impact of the institutional designs on the qualities of GHG inventories. An increasing number of GHG inventories is expected to become available under the Paris Agreement, which will enable to conduct cross-country and/or time-series analyses of their qualities, and examine whether there are any institutional factors that may differentiate the qualities.

\section{ACKNOWLEDGMENT}

This work was supported by the Mitsui \& Co. Environment Fund and JSPS KAKENHI Grant Number 18H03449. The opinions expressed in this paper are those of the authors and do not represent the views of the organizations to which the authors belong.

\section{REFERENCES}

[1] UNFCCC. (2015). Report of the Conference of the Parties on its twenty-first session, held in Paris from 30 November to 13 December 2015. https://unfccc.int/sites/default/files/english_paris_agree ment.pdf, accessed on May 30, 2017.

[2] 2006 IPCC Guidelines for National Greenhouse Gas Inventories. (2006). National Greenhouse Gas Inventories Programme, Kanagawa, Japan.

[3] Aguirre-Villegas, H.A., Larson, R.A. (2017). Evaluating greenhouse gas emissions from dairy manure management practices using survey data and lifecycle tools. Journal of Cleaner Production, 143: 169-179. https://doi.org/10.1016/j.jclepro.2016.12.133

[4] Pearson, T.R.H., Brown, S., Murray, L., Sidman, G. (2017). Greenhouse gas emissions from tropical forest degradation: An underestimated source. Carbon Balance and Management, 12(3): 1-11. https://doi.org/10.1186/s13021-017-0072-2

[5] Pereira, J.L.S. (2017). Assessment of ammonia and greenhouse gas emissions from broiler houses in Portugal. Atmospheric Pollution Research, 8(5): 949-955. https://doi.org/10.1016/j.apr.2017.03.011

[6] Crooks, S., Sutton-Grier, A.E., Troxler, T.G., Herold, N., Bernal, B., Schile-Beers, L., Wirth T. (2018). Coastal wetland management as a contribution to the US national greenhouse gas inventory. Nature Climate Change, 8: 1109-1112. https://doi.org/10.1038/s41558-018-0345-0

[7] Kurz, W.A., Hayne, S., Fellows, M., MacDonald, J.D., Metsaranta, J.M., Hafer, M., Blain, D. (2018). Quantifying the impacts of human activities on reported greenhouse gas emissions and removals in Canada's managed forest: Conceptual framework and implementation. Canadian Journal of Forest Research, 48: 1227-1240. https://doi.org/10.1139/cjfr-2018-0176

[8] Sato, A., Nojiri, Y. (2019). Assessing the contribution of harvested wood products under greenhouse gas estimation: Accounting under the Paris Agreement and the potential for double-counting among the choice of approaches. Carbon Balance and Management, 14(15): 1-19. https://doi.org/10.1186/s13021-019-0129-5

[9] Tiemeyer, B., Freibauer, A., Borraz, E.A., Augustin, J., Bechtold, M., Beetz, S., Beyer, C., Ebli, M., Eickenscheidt, T., Fiedler, S., Förster, C., Gensior, A., Giebels, M., Glatzel, S., Heinichen, J., Hoffmann, M., Höper, H., Jurasinski, G., Laggner, A., Leiber-Sauheitl, K., Peichl-Brak, M., Drösler, M. (2020). A new methodology for organic soils in national greenhouse gas inventories: Data synthesis, derivation and application. Ecological Indicators, 109(105838): 1-14. https://doi.org/10.1016/j.ecolind.2019.105838

[10] Pulles T. (2017). Did the UNFCCC review process improve the national GHG inventory submissions? Carbon Management, 8(1): 19-31. https://doi.org/10.1080/17583004.2016.1271256

[11] Jarnicka, J., Żebrowski, P. (2019). Learning in greenhouse gas emission inventories in terms of uncertainty improvement over time. Mitigation and Adaptation Strategies for Global Change, 24: 1143-1168. https://doi.org/10.1007/s11027-019-09866-5

[12] Bustamante, M.M.C., Silva, J.S.O., Cantinho, R.Z., Shimbo, J.Z., Oliveira, P.V.C., Santos, M.M.O., Ometto, J.P.H.B., Cruz, M.R., Mello, T.R.B., Godiva, D., Nobre, C.A. (2018). Engagement of scientific community and transparency in $\mathrm{C}$ accounting: The Brazilian case for anthropogenic greenhouse gas emissions from land use, land-use change and forestry. Environmental Research Letters, 13: 055005. https://doi.org/10.1088/17489326/aabb37

[13] Kawanishi, M., Kato, M., Matsuda, E., Fujikura, M., Fujikura, R. (2020). Comparative study on institutional designs and performance of national greenhouse gas inventories: The cases of Vietnam and the Philippines. Environment, Development and Sustainability, 22: 59475964. https://doi.org/10.1007/s10668-019-00460-y

[14] Kawanishi, M., Morizane, J., Lubis, N.A., Fujikura, R. (2020). Issue interpretations and implementation analysis for the national greenhouse gas inventory: The case of Indonesia. Journal of Environmental Studies and Sciences, $10(4)$ : 411-425. https://doi.org/10.1007/s13412-020-00628-3

[15] Kawanishi, M., Fujikura, R. (2020). Assessment for the implementation of the national greenhouse gas inventory: The case of Japan. Management of Environmental Quality. https://doi.org/10.1108/MEQ-06-2020-0116

[16] Umemiya, C., White, M., Amellina, A., Shimizu, N. (2017). Greenhouse gas emissions inventory capacity: An assessment of Asian developing countries. Environmental Science and Policy, 78: 66-73. 
https://doi.org/10.1016/j.envsci.2017.09.008

[17] Umemiya, C., Ikeda, M., White, M.K. (2020). Lessons learned for future transparency capacity building under the Paris Agreement: A review of greenhouse gas inventory capacity building projects in Viet Nam and Cambodia. Journal of Cleaner Production, 245: 118881. https://doi.org/10.1016/j.jclepro.2019.118881

[18] Hood, C. (1986). Administrative Analysis: An Introduction to Rules, Enforcement and Organizations. Wheatsheaf Book, Sussex, 100-104.

[19] Chayes, A., Chayes, A.H. (1995). The New Sovereignty: Compliance with International Regulatory Agreements. Harvard University Press, Cambridge, MA.

[20] Ausubel, J.H., Victor, D.G. (1992). Verification of international environmental agreements. Annual Review of Energy and the Environment, 17: 1-43. https://doi.org/10.1146/annurev.eg.17.110192.000245

[21] United States General Accounting Office. (1992). International environment: Strengthening the implementation of environmental agreements. https://www.gao.gov/assets/220/216570.pdf, accessed on Feb. 7, 2018.

[22] Obergassel, W., Arens, C., Hermwille, L., Kreibich, N., Mersmann, F., Ott, H.E., Wang-Helmreich, H. (2015). Phoenix from the ashes: An analysis of the Paris Agreement to the United Nations Framework Convention on Climate Change - Part 1. Environmental Law and Management, 27(6): 243-262.

[23] Falkner, R. (2016). The Paris Agreement and the new logic of international climate politics. International Affairs, 92(5): 1107-1125. https://doi.org/10.1111/14682346.12708

[24] Bodansky, D. (2016). The Paris climate change agreement: A new hope? American Journal of International Law, 110(2): 288-319. https://doi.org/10.5305/amerjintelaw.110.2.0288

[25] Rajamani, L. (2016). Ambition and differentiation in the 2015 Paris Agreement: Interpretative possibilities and underlying politics. International and Comparative Law Quarterly, 65(2):

493-514. https://doi.org/10.1017/S0020589316000130

[26] UNFCCC. United Nations Framework Convention on Climate https://unfccc.int/sites/default/files/conveng.pdf, accessed May 21, 2017.

[27] UNFCCC. Report of the Conference of the Parties on its sixteenth session, held in Cancun from 29 November to $10 \quad$ December 2010. https://unfccc.int/sites/default/files/resource/docs/2010/ cop16/eng/07a01.pdf, accessed on May 21, 2017.

[28] UNFCCC. Report of the Conference of the Parties on its seventeenth session, held in Durban from 28 November to $11 \quad$ December 2011. https://unfccc.int/sites/default/files/resource/docs/2011/ cop17/eng/09a01.pdf, accessed on May 21, 2017.

[29] UNFCCC. Report of the Conference of the Parties on its seventeenth session, held in Durban from 28 November to 11 December 2011: Addendum. https://unfccc.int/sites/default/files/resource/docs/2011/ cop17/eng/09a02.pdf, accessed on May 21, 2017.

[30] Williamson, O.E. (1975). Markets and Hierarchies. Collier Macmillan, London.

[31] IPCC. Revised 1996 IPCC guidelines for national greenhouse gas inventories. https://www.ipcc.ch/report/revised-1996-ipccguidelines-for-national-greenhouse-gas-inventories, accessed on Oct. 31, 2019.

[32] UNFCCC. Roster of experts. https://www4.unfccc.int/sites/roestaging/Pages/RosterO fExperts.aspx, accessed on Nov. 19, 2020.

[33] World Bank. Researchers in R\&D. https://data.worldbank.org/indicator/SP.POP.SCIE.RD. P6, accessed on Nov. 19, 2020.

[34] Damassa, T., Elsayed, S. (2013) From the GHG measurement frontline: A synthesis of non-Annex I country national inventory system practices and experiences. World Resource Institute, Washington, DC.

[35] UNFCCC. National communication submissions from non-Annex I Parties. https://unfccc.int/process-andmeetings/transparency-and-reporting/reporting-andreview-under-the-convention/national-communicationsand-biennial-update-reports-non-annex-iparties/national-communication-submissions-from-nonannex-i-parties, accessed on Nov. 19, 2020.

[36] UNFCCC. Biennial update report submissions from nonAnnex I Parties. https://unfccc.int/process-andmeetings/transparency-and-reporting/reporting-andreview-under-the-convention/national-communicationsand-biennial-update-reports-non-annex-iparties/biennial-update-report-submissions-from-nonannex-i-parties, accessed on Nov. 19, 2020.

[37] President of Indonesia. Presidential Regulation of the Republic of Indonesia No. 165/2014 on arrangement of duties and functions of the cabinet. https://www.globalregulation.com/translation/indonesia/2962997/president ial-regulation-number-165-by-2014.html, accessed on Jun. 18, 2019.

[38] President of Indonesia. Presidential Regulation of the Republic of Indonesia No. 16/2015 on the Ministry of Environment and Forestry. https://www.ecolex.org/details/legislation/presidentialregulation-of-the-ri-no-16-of-2015-concerning-theministry-of-environment-and-forestry-lex-faoc174324, accessed on Jun. 18, 2019.

[39] Ministerial Regulation No. P.18/MENLHK-II/2015 on organization and functions of the Ministry of Environment and Forestry (unpublished translation). (2015). Jakarta, Indonesia.

[40] Young, O.R. (2002). The Institutional Dimensions of Environmental Change: Fit, Interplay, and Scale. The MIT Press, Cambridge, MA.

[41] Gupta, J. (2008). Global change: Analyzing scale and scaling in environmental governance. In: Young, O.R., King, L.A., Schroeder, H. (eds) Institutions and Environmental Change: Principal Findings, Applications, and Research Frontiers. The MIT Press, Cambridge, MA.

[42] AFD, JICA. Joint evaluation: Indonesia climate change programme

loan. https://www.afd.fr/sites/afd/files/imported-

files/Evaluation-conjointe-indonesia-climate-changeiccpl.pdf, accessed on Jun. 18, 2019.

[43] JICA. Final report on the Project of Capacity Development for Climate Change Strategies in Indonesia. http://open_jicareport.jica.go.jp/pdf/1000028820.pdf, accessed on Jun. 18, 2019.

[44] Ministerial Regulation No. P.73/MENLHK/SETJEN/KUM.1/12/2017 on national GHG inventory implementation and reporting guidelines 
(unpublished translation). (2017). Jakarta, Indonesia.

[45] KLHK. Indonesia third national communication under the United Nations Framework Convention on Climate Change.

https://unfccc.int/sites/default/files/resource/8360571_I ndonesia-NC3-2-

Third $\% 20$ National $\% 20$ Communication $\% 20-\% 20$ Indone sia\%20-\%20editorial\%20refinement\%2013022018.pdf, accessed on Jun. 18, 2019.

[46] KLHK. Indonesia second biennial update report under the United Nations Framework Convention on Climate Change. https://unfccc.int/sites/default/files/resource/Indonesia2nd_BUR.pdf, accessed on Jun. 18, 2019.

[47] KLHK. Indonesia first biennial update report under the United Nations Framework Convention on Climate Change.

https://unfccc.int/sites/default/files/resource/IDNBUR1. pdf, accessed on Jun, 18, 2019.

[48] UNFCCC. Technical analysis of the second biennial update report of Indonesia submitted on 21 December 2018. https://unfccc.int/documents/209512, accessed on Apr. 17, 2020.

[49] MONRE. The third national communication of Vietnam to the United Nations Framework Convention on Climate Change. https://unfccc.int/documents/192805, accessed on Sep. 28, 2019.

[50] Thu Vien Pha Pluat. Vietnam Prime Minister's Decision No. 2359/QD-TTg (English translation). https://thuvienphapluat.vn/van-ban/Tai-nguyen-Moitruong/Quyet-dinh-2359-QD-TTg-duyet-he-thongquoc-gia-kiem-ke-khi-nha-kinh-2015-299344.aspx, accessed on Sep. 18, 2018.

[51] JICA. Project for Capacity Building for National Greenhouse Gas Inventory: Internal ex-post evaluation. https://www2.jica.go.jp/en/evaluation/pdf/2017_090044 9_4.pdf, accessed on Sep. 23, 2019.

[52] MONRE. The initial biennial updated report of Vietnam to the United Nations Framework Convention on Climate Change. https://unfccc.int/sites/default/files/resource/bur1vietna m.pdf, accessed on Jun. 11, 2017.

[53] UNFCCC. Summary report on the technical analysis of the first biennial update report of Vietnam submitted on $8 \quad$ December 2014. https://unfccc.int/sites/default/files/resource/docs/2015/t asr/vnm.pdf, accessed on Nov. 1, 2018.

[54] MONRE. The second biennial updated report of Vietnam to the United Nations Framework Convention on Climate Change.

https://unfccc.int/sites/default/files/resource/97620135_ Viet\%20Nam-BUR2-1-

Viet\%20Nam\%20-\%20BUR2.pdf, accessed on Aug. 26, 2018.

[55] UNFCCC. Technical analysis of the second biennial update report of Vietnam submitted on 20 November 2017.

https://unfccc.int/sites/default/files/resource/tasr2018_V NM.pdf, accessed on Nov. 1, 2018.

[56] ONEP. Second biennial update report of Thailand. https://unfccc.int/sites/default/files/resource/347251_Th ailand-BUR2-1-SBUR\%20THAILAND.zip, accessed on Sep. 28, 2019.

[57] ONEP. Thailand's third national communications. https://unfccc.int/sites/default/files/resource/Thailand\% 20TNC.pdf, accessed on Sep. 28, 2019.

[58] JICA. Project for Capacity Development to Accelerate Low Carbon and Resilient Society Realization in the Southeast Asia Region. https://www.jica.go.jp/project/english/thailand/029/outli ne/index.html, accessed on Sep. 23, 2019.

[59] ONEP. Thailand's first biennial update report under the United Nations Framework Convention on Climate Change. https://unfccc.int/sites/default/files/resource/THABUR1 .pdf, accessed on Sep. 28, 2019.

[60] UNFCCC. Technical analysis of the second biennial update report of Thailand submitted on 29 December 2017. https://unfccc.int/sites/default/files/resource/tasr2018_T HA.pdf, accessed on Sep. 28, 2019. 